\title{
KARAKTERISTIK KEJADIAN FILARIASIS DI PROVINSI SUMATERA UTARA
}

\author{
Rahmadani Sitepu, Sinta Veronica, Nanda Novziransyah \\ Universitas Islam Sumatera Utara, Jl. STM No. 77, Medan \\ Email: drrsitepu@gmail.com
}

\begin{abstract}
This study aims to characteristics of Filariasis Patients in North Sumatra Province in 2010-2017. This research used descriptive study with case report desained. This sampling was carried out using secondary data obtained from North Sumatra province in the period 2010-2017. The sample of this study was 33 districts / cities taken using the total sampling method. The sample selection is based on secondary data obtained from North Sumatera Province. The highest proportion of Filariasis sufferers in the age category is end adult as many as 16 patients (19.8\%), the highest sex is more prevalent in 52 patients $(64.2 \%), 23$ Most lymphedema in filariasis patients is in Right Lower Legs (28.4\%), Based on the year began to live as many as 52 patients over 10 years (64.2\%), Based on the year starting from the illness, there were 52 patients over 10 years $(64.2 \%)$, and by region found as many as 16 sufferers in center tapanuli (19.8\%).
\end{abstract}

\section{Keywords: Filariasis, Characteristics, filariasis patient}

\section{PENDAhULUAN}

Filariasis limfatik, umumnya dikenal sebagai elephantiasis, adalah penyakit tropis yang terabaikan. Infeksi terjadi ketika parasit filaria ditularkan ke manusia melalui nyamuk. Infeksi biasanya didapat pada masa kanakkanak yang menyebabkan kerusakan tersembunyi pada sistem limfatik. Orang dengan penyakit ini dapat menderita lymphedema dan elephantiasis dan pada pria, pembengkakan skrotum, disebut hidrokel. Filariasis limfatik adalah penyebab utama kecacatan permanen di seluruh dunia. Masyarakat sering menghindari dan menolak perempuan dan laki-laki yang cacat akibat penyakit tersebut. Orang yang terkena dampak sering tidak dapat bekerja karena cacat mereka, dan ini membahayakan keluarga dan komunitas mereka (CDC, 2018).

Filariasis limfatik adalah salah satu penyakit yang paling melumpuhkan dan menodai dunia. Paling sering ditemukan di antara populasi miskin dan rentan, sering di komunitas terpencil yang tidak memiliki akses ke perawatan kesehatan dasar. Selain rasa sakit fisik, orang yang hidup dengan penyakit ini dapat menderita stigma sosial yang luar biasa. Kecacatan dan kecacatan dari LF sering mencegah individu dari bekerja, menyediakan bagi keluarga mereka, atau menjadi anggota aktif dari komunitas mereka, yang mengakibatkan kerugian mental dan finansial yang berkontribusi pada siklus kemiskinan (USAID, 2018).

Penyakit filariasis dapat berupa filariasis tanpa gejala dan dengan gejala peradangan. Filariasis tanpa gejala umumnya terjadi di daerah endemik. Pada pemeriksaan fisik hanya ditemukan pembesaran kelenjar limfe terutama di daerah inguinal. Pada pemeriksaan darah ditemukan mikrofilaria dalam jumlah besar dan eosinofilia. Filariasis dengan peradangan dapat berupa demam, menggigil, sakit kepala, muntah dan lemah 


\begin{tabular}{c|c|c}
\hline JURNAL PENELITIAN KESMASY & VOL.1 NO. 2 & $\begin{array}{c}\text { EDITION: NOVEMBER 2018 - } \\
\text { APRIL 2019 }\end{array}$ \\
\hline \multirow{2}{*}{ RECEIVED: 6 JANUARI 2019} & http://ejournal.delihusada.ac.id/index.php/JPKSY & \\
\cline { 2 - 3 } & REVISED: 8 FEBRUARI 2019 & ACCEPTED: 15 MARET 2019 \\
\hline
\end{tabular}

yang dapat berlangsung beberapa hari sampai beberapa minggu. Pada laki-laki umumnya terdapat funikulitis disertai penebalan dan rasa nyeri, epididimitis, orkitis, dan pembengkakan skrotum. Pada wanita dapat terjadi elephantiasis pada vagina dan payudara (WHO, 2010).

Kecacatan fisik yang dialami oleh penderita filariasis memberikan dampak pada mobilitas fisik, psikologis, sosial, dan ekonomi. Kecacatan fisik sangat menghambat aktivitas sehari-hari penderita filariasis, seperti memasak, menjaga, atau merawat anakanak. Kecacatan fisik akan menimbulkan perasaan malu, takut diketahui orang lain, sehingga penderita menarik diri dari lingkungannya; kemudian kehilangan pekerjaan, yang selanjutnya berdampak terhadap ekonominya (Lismayanti, 2013).

Kecacatan yang irreversible merupakan pemicu utama bagi penderita filariasis terjadinya gangguan psikologis berupa perasaan malu, kecemasan, depresi, bahkan ada upaya untuk bunuh diri. Kejadian tersebut berulang, sehingga mengakibatkan kecemasan karena selalu ada kekhawatiran bahwa serangan akan terjadi lagi di depan banyak orang. Sebagian besar penderita mengatakan bahkan berpikir untuk mengakhiri hidup mereka dari pada menanggung penderitaannya (Lismayanti, 2013).

Kecacatan akibat filariasis tidak hanya berdampak terhadap psikologisnya, tetetapi juga akan berdampak terhadap keadaan sosial dan ekonomi penderita. Kecacatan fisik akan menimbulkan perasaan malu, takut diketahui orang lain, sehingga penderita menarik diri dari lingkungannya; kemudian kehilangan pekerjaan, yang selanjutnya berdampak terhadap ekonominya (Lismayanti, 2013).

Filariasis menyebar hampir di seluruh wilayah Indonesia. Dari tahun ke tahun jumlah provinsi yang melaporkan kasus filariasis terus bertambah. Bahkan di beberapa daerah mempunyai tingkat endemisitas yang cukup tinggi. Lingkungan sangat berpengaruh terhadap distribusi kasus filariasis dan mata rantai penilarannya. Biasanya daerah endemis Brugia Malayi adalah daerah sungai, hutan, rawa-rawa, sepanjang sungai atau badan air lain yang ditumbuhi tanaman air. Daerah endemis $W$. Bancrofi tipe perkotaan (urban) adalah daerah-daerah perkotaan yang kumuh, padat penduduknya dan banyak genangan air kotor sebagai habitat dari vector yaitu nyamuk $C X$. Quinquefasciatus. Sedangkan daerah endemis $W$. Bancrofi tipe pedesaan secara umum kondisi lingkungannya sama dengan daerah endemis B. Malayi (Infodatin, 2015).

Kasus filariasis pada Tahun 2014 telah menyerang lebih dari 1.103 juta orang di 73 negara. Kasus filariasis menyerang 632 juta (57\%) penduduk yang tinggal di Asia Tenggara (9 negara endemis) dan 410 juta $(37 \%)$ penduduk yang tinggal di wilayah Afrika (35 negara endemis). Sedangkan sisanya (6\%) diderita oleh penduduk yang tinggal di wilayah Amerika (4 negara endemis) (WHO, 2016).

Di Indonesia berdasarkan laporan tahun 2015, tiga provinsi dengan jumlah kasus terbanyak filariasis adalah Nusa Tenggara Timur (2.864 orang), Nanggroe Aceh Darussalam (2.372 orang), Papua Barat (1.244 orang) dan Sumatera Utara (444 orang). Empat provinsi dengan kasus terendah adalah Kalimantan Utara (11 orang), Nusa Tenggara Barat (14 orang), Bali (18 orang). Kejadian filariasis di NTT sangat menonjol bila dibandingkan dengan provinsi lain dan merupakan provinsi dengan jumlah kasus tertinggi di seluruh Indonesia. Hal ini memerlukan perhatian untuk ditindak lanjuti, dan dicari kemungkinan penyebabnya. (Infodatin, 2015).

Berdasarkan hal-hal tersebut diatas peneliti tertarik untuk melihat karakteristik kejadian filariasis di Sumatera Utara pada tahun 20102017. 


\begin{tabular}{c|c|c}
\hline JURNAL PENELITIAN KESMASY & VOL.1 NO. 2 & $\begin{array}{c}\text { EDITION: NOVEMBER 2018 - } \\
\text { APRIL 2019 }\end{array}$ \\
\hline \multirow{2}{*}{ RECEIVED: 6 JANUARI 2019} & http://ejournal.delihusada.ac.id/index.php/JPKSY & \\
\cline { 2 - 3 } & REVISED: 8 FEBRUARI 2019 & ACCEPTED: 15 MARET 2019 \\
\hline
\end{tabular}

\section{METODE PENELITIAN}

Jenis penelitian ini menggunakan metode survei deskriptif case report untuk mengetahui karakteristik kejadian filariasis di 33 kabupaten / kota di seluruh wilayah provinsi Sumatera Utara pada periode tahun 2010-2017. Waktu Penelitian yang akan dilakukan ini pada bulan desember 2018.

Populasi dan sampel pada peneliti an ini adalah semua penderita filariasis di 33 kabupaten / kota di seluruh wilayah provinsi Sumatera Utara dengan menggunakan metode total sampling dari seluruh data sekunder penderita filariasis dari tahun 20102017 di wilayah provinsi Sumatera Utara.

Teknik pengambilan sampel merupakan cara yang digunakan untuk dapat memperoleh sampel yang representative (mewakili populasinya). Pengambilan dilakukan dengan metode total sampling, dimana seluruh populasi diikutsertakan menjadi sampel.

Teknik pengumpulan data dalam penelitian penelitian karakteristik kejadian filariasis di wilayah provinsi sumatera utara pada tahun 2010-2017 ini adalah data sekunder filariasis di wilayah provinsi Sumatera Utara.

Metode penelitian ini menggunakan Analisis univariat bertujuan untuk menjelaskan atau mendeskripsikan karakteristik setiap variable penelitian. Bentuk analisis univariate tergantung dari jenis datanya.

\section{HASIL PENELITIAN}

Sampel yang diguanakan ada sebanyak 81 orang penderita filariasis yang tersebar di seluruh daerah Sumatera Utara. Karakteristik sampel yang ada direpresentasikan dalam tabel distribusi frekuensi berikut ini.
Tabel 1 Karakteristik Penderita Filariasis Berdasarkan Usia

\begin{tabular}{|c|c|c|}
\hline Usia & $\mathrm{f}$ & $(\%)$ \\
\hline Balita & 3 & 3,7 \\
\hline Remaja Awal & 7 & 8,6 \\
\hline Remaja Akhir & 7 & 8,6 \\
\hline Dewasa Awal & 11 & 13,6 \\
\hline Dewasa Akhir & 16 & 19,8 \\
\hline Lansia Awal & 12 & 14,8 \\
\hline Lansia Akhir & 11 & 13,6 \\
\hline Manula & 14 & 17,3 \\
\hline Total & 81 & 100,0 \\
\hline
\end{tabular}

Tabel 1 menunjukan bahwa Karakteristik Penderita Filariasis di tahun 2010-2017 berdasarkan Usia yaitu 13 Penderita pada usia Balita $(3,7 \%), 7$ penderita pada usia Remaja Awal $(8,6 \%), 7$ penderita pada usia Remaja Akhir $(8,6 \%), 11$ penderita pada usia Dewasa Awal $(13,6 \%), 16$ penderita pada usia Dewasa Akhir (19,8\%), 12 penderita pada usia Lansia Awal $(14,8 \%), 11$ penderita pada usia Lansia Akhir $(13,6)$ dan 14 penderita pada usia Manula (17,3\%).

Selain berdasarkan tingkatan usia, sampel juga dibedakan berdasarkan jenis kelamin, yang dinyatakan dalam tabel berikut.

Tabel 2 Karakteristik Penderita Filariasis Berdasarkan Jenis Kelamin

\begin{tabular}{ccc}
\hline Jenis Kelamin & $\mathrm{f}$ & $(\%)$ \\
\hline Laki-laki & 52 & 64,2 \\
Perempuan & 29 & 35,8 \\
\hline Total & 81 & 100,0 \\
\hline
\end{tabular}

Tabel 2 menunjukkan bahwa berdasarkan Jenis Kelamin yaitu 52 Penderita Lakilaki(64,2\%) dan 29 penderita Perempuan $(35,8 \%)$.

Banyak bagian tubuh yang terinfeksi filariasis, berikut ini adalah bagian limfadema yang terinfeksi filariasis. 


\begin{tabular}{|c|c|c|}
\hline JURNAL PENELITIAN KESMASY & VOL.1 NO. 2 & $\begin{array}{c}\text { EDITION: NOVEMBER 2018- } \\
\text { APRIL 2019 }\end{array}$ \\
\hline \multirow{2}{*}{ RECEIVED: 6 JANUARI 2019} & http://ejournal.delihusada.ac.id/index.php/JPKSY & \\
\cline { 2 - 3 } & REVISED: 8 FEBRUARI 2019 & ACCEPTED: 15 MARET 2019 \\
\hline
\end{tabular}

Tabel 3 Karakteristik Penderita Filariasis Berdasarkan Limfadema

\begin{tabular}{lcc}
\hline \multicolumn{1}{c}{ Limfadema } & $\mathrm{f}$ & $(\%)$ \\
\hline Payudara & 1 & 1,2 \\
Lengan bawah kanan & 4 & 4,9 \\
Lengan bawah kiri & 1 & 1,2 \\
Seluruh lengan bawah & 1 & 1,2 \\
Seluruh lengan kanan & 10 & 12,3 \\
Seluruh lengan (kanan, kiri) & 5 & 6,2 \\
Seluruh lengan kiri & 9 & 11,1 \\
Seluruh tungkai kanan & 1 & 1,2 \\
Seluruh tungkai (kanan, kiri), & 1 & 1,2 \\
Buah zakar & & \\
Seluruh tungkai kiri & 4 & 4,9 \\
Seluruh tungkai (kiri, kanan) & 1 & 1,2 \\
Tungkai bawah kanan & 23 & 28,4 \\
Tungkai bawah (kanan, Kiri), & 1 & 1,2 \\
Seluruh tungkai kiri & & \\
Tungkai bawah (kanan, kiri) & 5 & 6,2 \\
Tungkai bawah kiri & 14 & 17,3 \\
\hline \multicolumn{1}{c}{ Total } & 81 & 100,0 \\
\hline
\end{tabular}

Tabel 3 menunjukan jumlah Penderita Filariasis berdasarkan Limfadema yaitu 1 penderita payudara $(1,2 \%), 4$ penderita pada lengan bawah kanan $(4,9 \%), 1$ penderita pada lengan bawah kiri $(1,2 \%), 1$ penderita pada seluruh lengan bawah $(1,2 \%), 10$ penderita pada seluruh lengan kanan $(12,3 \%), 5$ penderita pada seluruh lengan kanan dan seluruh lengan kiri $(6,2 \%), 9$ penderita pada seluruh lengan kiri $(11,1 \%)$, 1 penderita pada seluruh tungkai kanan $(1,2 \%), 1$ penderita pada seluruh tungkai kanan, seluruh tungkai kiri dan buah zakar $(1,2 \%), 4$ penderita pada seluruh tungkai kiri $(4,9 \%), 1$ penderita pada seluruh tungkai kiri dan seluruh tungkai kanan $(1,2 \%), 23$ penderita pada tungkai bawah kanan $(28,4 \%), 1$ penderita pada tungkai bawah kanan dan seluruh tungkai kiri $(1,2 \%), 5$ penderita pada tungkai bawah kanan dan tungkai bawah kiri $(6,2 \%)$ dan 14 penderita pada tungkai bawah kiri $(17,3 \%)$.
Tabel 4 Karakteristik Penderita Filariasis Berdasarkan Tahun Mulai Tinggal

\begin{tabular}{lll}
\hline Tahun Mulai Tinggal & $\mathrm{f}$ & $(\%)$ \\
\hline$<5$ tahun & 10 & 12,3 \\
$>10$ tahun & 52 & 64,2 \\
$5-10$ tahun & 19 & 23,5 \\
\hline Total & 81 & 100,0 \\
\hline
\end{tabular}

Tabel 4 menunjukan masa tinggal seseorang yaitu 10 penderita di Bawah 5 Tahun $(12,3 \%), 52$ penderita di Atas 10 Tahun $(64,2 \%), 19$ penderita 5 sampai 10 Tahun (23,5\%).

Tabel 5 Karakteristik Penderita Filariasis Berdasarkan Masa

\begin{tabular}{lll}
\hline Masa Derita & $\mathrm{f}$ & $(\%)$ \\
\hline$<5$ tahun & 10 & 12,3 \\
$>10$ tahun & 52 & 64,2 \\
$5-10$ tahun & 19 & 23,5 \\
\hline Total & 81 & 100,0 \\
\hline
\end{tabular}

Tabel 5 menunjukan bahwa Karakteristik Penderita Filariasis, yaitu 10 orang telah menderita kurang dari 5 Tahun (12,3\%), 52 orang menderita lebih dari 10 Tahun $(64,2 \%)$, dan 19 orang menderita selama antara 5 sampai 10 Tahun (23,5\%).

Tabel 6 Karakteristik Penderita Filariasis Berdasarkan Daerah Asal

\begin{tabular}{lll}
\hline Daerah & $\mathrm{f}$ & $(\%)$ \\
\hline Asahan & 8 & 9,9 \\
Batu Bara & 7 & 8,6 \\
Binjai & 1 & 1,2 \\
Dairi & 2 & 2,5 \\
Deli Serdang & 1 & 1,2 \\
Gunung Sitoli & 1 & 1,2 \\
Humbahas & 1 & 1,2 \\
Karo & 1 & 1,2 \\
Lab. Batu & 1 & 1,2 \\
Lab. Batu Selatan & 1 & 1,2 \\
Lab.Batu Utara & 1 & 1,2 \\
Langkat & 8 & 9,9 \\
Madina & 1 & 1,2 \\
Medan & 4 & 4,9 \\
Nias & 1 & 1,2
\end{tabular}




\begin{tabular}{lll}
\hline \multicolumn{2}{c}{ JURNAL PENELITIAN KESMASY } & \\
\hline & & http://ejournal.delihu \\
\cline { 3 - 3 } \multicolumn{1}{c}{ RECEIVED: 6 JANUARI 2019 } & \\
\hline & & $(\%)$ \\
\hline Daerah & $\mathrm{f}$ & 11,1 \\
\hline Nias Barat & 9 & 1,2 \\
Nias Selatan & 1 & 1,2 \\
Nias Utara & 1 & 3,7 \\
P. Siantar & 3 & 1,2 \\
P. Sidempuan & 1 & 1,2 \\
Pakpak Barat & 1 & 1,2 \\
Palas & 1 & 1,2 \\
Paluta & 1 & 1,2 \\
Samosir & 1 & 1,2 \\
Serdang Bedagai & 1 & 1,2 \\
Sibolga & 1 & 1,2 \\
Simalungun & 1 & 1,2 \\
Tap.Selatan & 1 & 19,8 \\
Tap.Tengah & 16 & 1,2 \\
Tap.Utara & 1 & 1,2 \\
Tebing Tinggi & 1 & 1,2 \\
Tobasa & 1 & \\
\hline
\end{tabular}

Tabel 6 menunjukan bahwa berdasarkan Daerah yaitu 8 Penderita di Asahan (9,9\%), 7 penderita di Batu Bara 98,6\%), 1 penderita di Binjai (1,2\%), 2 penderita di Dairi $(2,5 \%)$, 1 penderita di Deli Serdang (1,2\%), 1 penderita di Gunung Sitoli $(1,2 \%), 1$ penderita di Humbahas $(1,2 \%), 1$ penderita di Karo $(1,2 \%), 1$ penderita di Lab.Batu $(1,2 \%), 1$ penderita di Lab.Batu Selatan $(1,2 \%), 1$ penderita di Lab.Batu Utara $(1,2 \%), 8$ penderita di Langkat $(9,9 \%), 1$ penderita di Madina (1,2\%), 4 penderita di Medan (4,9\%), 1 penderita di Nias (1,2\%), 9 penderita di Nias Barat $(11,1 \%), 1$ penderita di Nias Selatan $(1,2 \%), 1$ penderita di Nias Utara $(1,2 \%), 3$ penderita P.Siantar $(3,7 \%)$, 1 penderita di P.Sidempuan (1,2\%), 1 penderita di Pakpak Barat $(1,2 \%), 1$ penderita di Palas $(1,2 \%), 1$ penderita di Paluta $(1,2 \%), 1$ penderita di Samosir $(1,2 \%), 1$ penderita di Serdang Bedagai $(1,2 \%), 1$ penderita di Sibolga $(1,2 \%), 1$ penderita di Simalungun (1,2\%), 1 penderita di Tap.Selatan $(1,2 \%), 16$ penderita di Tap.Tengah $(19,8 \%), 1$ penderita di Tap.Utara $(1,2 \%), 1$ penderita di Tebing Tinggi (1,2\%) dan 1 penderita di Tobasa $(1,2 \%)$.

\section{PEMBAHASAN}

Dari hasil penelitian ini menunjukan bahwa dari 81 penderita Filariasis, usia yang tertinggi yaitu Usia Dewasa Akhir sebanyak 16 penderita $(19,8 \%)$ dan yang terendah yaitu Usia Balita sebanyak 3 penderita $(3,7 \%)$. Penderita Filariasis yang tertinggiya itu pada usia di atas 14 tahun sebanyak 776 penderita filariasis. Sedangkan berdasarkan jenis kelamin yang tertinggi yaitu lebih banyak terjadi pada Laki-laki sebanyak 52 penderita $(64,2 \%)$. Ini menunjukkan bahwa umur seseorang, jenis kelamin, imunitas dan ras mempengaruhi terjadinya resiko kejadian Filariasis (Masrizal, 2013).

Sedangkan lokasi lesi yang terbanyak yaitu pada lokasi Tungkai Bawah Kanan sebanyak 23 penderita atau sebesar $52,6 \%$. Sementara pada bagian lengan, payudara dan alat kelamin tidak ditemukan tanda limfedema. Hal ini terkait kejadian filariasis di Kabupaten Meranti paling banyak disebabkan oleh Brugia malayi, pathogenesis penyumbatan limfe pada jenis ini terbatas hanya sampai ekstremitas inferior bagian dista sehingga limfedema yang ditemukan juga hanya terbatas pada tungkai bawah dan kaki serta tidak mengenai lengan, payudara dan alat kelamin.

Hal ini sesuai dengan teori bahwa limfedema pada filariasis malayi jarang terjadi pada lengan dan sangat jarang dapat menimbulkan pembengkakan pada payudara, saluran kemih serta kelamin. Limfedema pada filariasis malayi hanya mengenai tungkai bawah / di bawah lutut serta kadangkadang mengenai lengan bawah / di bawah siku.

Dari hasil penelitian ini menunjukkan bahwa pada penderita Filariasis Tahun Mulai Tinggal di daerah tersebut yaitu yang tertinggi pada penderita yang tinggal lebih dari 10 tahun sebanyak 52 dari 81 penderita filariasis. larva B. Malayi dan B. Timori akan menjadi cacing dewasa dalam kurun waktu 3,5 bulan. Sedangka W. Bancrofti memerlukan waktu 9 


\begin{tabular}{c|c|c}
\hline JURNAL PENELITIAN KESMASY & VOL.1 NO. 2 & $\begin{array}{c}\text { EDITION: NOVEMBER 2018 - } \\
\text { APRIL 2019 }\end{array}$ \\
\hline \multirow{2}{*}{ RECEIVED: 6 JANUARI 2019} & http://ejournal.delihusada.ac.id/index.php/JPKSY & \\
\cline { 2 - 3 } & REVISED: 8 FEBRUARI 2019 & ACCEPTED: 15 MARET 2019 \\
\hline
\end{tabular}

bulan. Cacing dewasa mampu bertahan hidup selama 5-7 tahun didalam kelenjar getah bening. Hal ini menunjukkan bahwa perlu kurun waktu yang lama untuk seseorang bisa terjangkit dengan penyakit filariasis.

Dari hasil penelitian ini menunjukkan bahwa penderita filariasis terbanyak mulai sakit yaitu di atas 10 tahun yaitu sebanyak 52 penderita dari 81 penderita filariasis. Dari hasil penelitian ini menunjukkan bahwa penderita filariasis terbanyak terdapat di kabupaten Tapanuli Tengah sebanyak 16 penderita dari 81 penderita filariasis.

Selain itu, lingkungan sekitar dan perubahan iklim turut meningkatkan resiko menderita filariasis. Pengelolaan lingkungan merupakan upaya pengendalian vektor nyamuk dengan mengurangi tempat perindukanya, disebutkan dalam penelitian Amelia (2014) bahwa responden yang disekitar rumahnya terdapat tempat perindukan nyamuk mempunyai risiko 8,556 kali menderita filariasis. Sehingga penting kiranya untuk lebih meningkatkan kegiatan meniadakan tempat perindukan nyamuk dengan 3M Plus: Mengubur, Menguras, Mendaur Ulang dan Mencegah gigitan nyamuk (Munawwaroh, 2016).

Keberadaan nyamuk Mansonia spp. yang merupakan vektor filariasis B. malayi di wilayah Sumatera memiliki kepadatan yang cukup tinggi. Tempat perkembangbiakan nyamuk yang ditemukan berupa rawa-rawa yang digenangi tanaman air yang merupakan tempat perkembangbiakan potensial bagi nyamuk Mansonia spp. Spesies mikrofilaria yang ditemukan di wilayah Sumatera bagian Selatan adalah Brugia malayi yang juga merupakan zoonosis. Penularan mikrofilaria jenis ini dapat terjadi dari manusia ke hewan dan sebaliknya. Hewan yang telah teridentifikasi sebagai hewan zoonosis adalah kera (Macaca fascicularis) dan kucing (Felis catus).

Daerah Tapanuli Tengah merupakan wilayah yang memiliki banyak daerah rawa-rawa yang cocok dengan habitat nyamuk Mansonia spp. Sehingga masyarakat diharapkan mampu menjaga dan mengelola lingkungan sekitarnya, selain juga membiasakan untuk hidup sehat.

Beberapa alasan banyaknya penderita filariasis di daerah Tapanuli Tengah adalah karena kebiasaan masyarakatnya, antara lain: sering keluar malam, kurangnya masyarakat yang menggunakan kelambu saat tidur, sedikit sekali masyarakat yang menggunakan obat anti nyamuk, banyaknya masyarakat yang menggantung pakaian di dalam kamar tidur, sedikitnya masyarakat yang menggunakan pakaian panjang (baju lengan panjang dan celana panjang) (Munawwaroh, 2016).

Responden dengan keberadaan barangbarang bergantung di rumah, khususnya di kamar tidur akan berisiko 6,3 kali lebih besar menderita filariasis (Juriastuti, dkk, 2010). Lebih lanjut, kebiasaan dan sikap seseorang dalam mengelola lingkungannya akan mampu mengurangi resiko penderita filariasis (Agustiantiningsih, 2013).

\section{KESIMPULAN}

Dari hasil penelitian yang dilakukan mengenai Karakteristik Penderita Filariasis dari Tahun 2010-2017, maka dapat ditarik kesimpulan bahwa:

1. Dari 81 penderita filariasis, usia tertinggi yang beresiko adalah pada Usia Dewasa Akhir yaitu 16 penderita (19,8\%), yang tertinggi terjadi pada Laki-laki yaitu 52 penderita $(64,2 \%)$, dan berdasarkan lokasi lesi yang paling banyak di dapati di Tungkai Bawah Kanan yaitu 23 penderita (28,4\%).

2. Dari 81 penderita filariasis, paling banyak terjadi pada penderita yang tinggal di daerah tersebut lebih dari 10 tahun yaitu 52 penderita $(64,2 \%)$. Mulai terjadinya sakit terbanyak di atas 10 tahun yaitu sebanyak 52 penderita $(64,2 \%)$,

3. Didapati bahwa Daerah yang memiliki resiko adalah di daerah kabupaten Tapanuli Tengah yaitu 16 penderita $(19,8 \%)$. 


\begin{tabular}{c|c|c}
\hline JURNAL PENELITIAN KESMASY & VOL.1 NO. 2 & $\begin{array}{c}\text { EDITION: NOVEMBER 2018 } \\
\text { APRIL 2019 }\end{array}$ \\
\hline \multirow{2}{*}{ RECEIVED: 6 JANUARI 2019} & http://ejournal.delihusada.ac.id/index.php/JPKSY & \multirow{2}{*}{ ACCEPTED: 15 MARET 2019 } \\
\cline { 2 - 3 } & REVISED: 8 FEBRUARI 2019 & \\
\hline
\end{tabular}

\section{DAFTAR PUSTAKA}

Agustiantiningsih,

D. 2013. Praktik Pencegahan Filariasis. Jurnal Kesehatan Masyarakat Unnes, Vol. 8 (2), p. 190-197.

Amelia, R. 2014. Analisis Faktor Risiko Kejadian Penyakit Filariasis. Unnes Journal of Public Health, Vol. 3 (1).

Centers for Disease Control and Prevention (CDC). 2018. Parasites- Lymphatic Filariasis. US Department Of Health and Disease: USA.

Infodatin (Pusat Data dan Informasi Kementrian Kesehatan RI) Filariasis. (2015). Filariasis.Diakses dari http: LWWW. depkes. go. id/ resources/download/pusdatin/infodatin $\angle$ infodatin-filariasis.pdf

Juriastuti, P., Kartika, M., Djaja, I.M., \& Susanna, D. 2010. Faktor Risiko Kejadian Filariasis di Kelurahan Jati Sampurna. Makara Kesehatan, Vol. 14 (1), p. 31-36

Jurnal Keperawatan padjajaran. (2016) Poltekkes Kemenkes Bandung. Diakses dari :http://pustaka.unpad.ac.id/wpcontent/uploads/2018/12/Jurnal-

Pengalaman-Hidup-Orang-TerinfeksiFilariasis.pdf.

Lismayanti, L., Ibrahim, K., \& Meilianingsih, L. (2013). Pengalaman Hidup Orang Terinfeksi Filariasis.

Masrizal. 2013. Penyakit Filariasis. Jurnal Kesehatan Masyarakat, Vol. 7 (1).

Munawwaroh, L., \& Pawenang, E.T. 2016. Evaluasi Program Eliminasi Filariasis Dariaspek Perilaku dan Perubahan Lingkungan. Unnes Journal of Public Health, Vol. 5 (3).

USAID. (2018). Lymphatic Filariasis. Negleted Tropical Disease Program : USA.

World Health Organization (WHO). (2010), Epidemiology Limphatic Filariasis. Diakses Dari : http://www.who.int/gho/neglected dis eases/lymphatic filariasis/en/

World Health Organization (WHO). (2016), Diakses: http://www.who.int/gho/neglected dis eases/lymphatic filariasis/en/ 